\title{
Research on SARS-COV-2 pandemic: a narrative review focused on the Italian contribution
}

\author{
Alessandro De Cassai ${ }^{*}$ (D), Federico Longhini², Stefano Romagnoli, ${ }^{3,4}$, Fabio Cavaliere ${ }^{5}$, Antonio Caroleo², \\ Lorenzo Foti, ${ }^{3,4}$, Elisa Furlani ${ }^{5}$, Sara Gianoli5 ${ }^{5}$ Francesco Monteleone ${ }^{5}$, Giuseppe Saraco ${ }^{2}$, Gianluca Villa ${ }^{3,4}$, \\ Giorgio Conti ${ }^{6}$ and Paolo Navalesi ${ }^{1,5}$
}

\begin{abstract}
Background: Since late 2019, a severe acute respiratory syndrome, caused by the severe acute respiratory syndrome coronavirus-2 (SARS-CoV-2), has spread with overwhelming speed causing over 214 million confirmed infections and more than 4.5 million deaths worldwide. In this framework, Italy had the second highest number of SARS-CoV-2 infections worldwide, and the largest number of deaths. A global effort of both the scientific community and governments has been undertaken to stem the pandemic. The aim of this paper is to perform a narrative review of the Italian contribution to the scientific literature regarding intensive care management of patients suffering from COVID19 , being one of the first western countries to face an outbreak of SARS-CoV-2 infection.

Main body: We performed a narrative review of the literature, dedicating particular attention and a dedicated paragraph to ventilatory support management, chest imaging findings, biomarkers, possible pharmacological interventions, bacterial superinfections, prognosis and non-clinical key aspects such as communication and interaction with relatives.
\end{abstract}

Conclusions: Many colleagues, nurses and patients died leaving their families alone. To all of them, we send our thoughts and dedicate these pages.

Keywords: COVID-19, SARS-COV 2, Italy, Review

\section{Introduction}

Since late 2019, a severe acute respiratory syndrome, caused by the severe acute respiratory syndrome coronavirus-2 (SARS-CoV-2), has spread with overwhelming speed causing over 214 million confirmed infections and more than 4.5 million deaths worldwide [1].

SARS-CoV-2 was first identified in Wuhan, Hubei province, central China, and initial efforts were directed

\footnotetext{
* Correspondence: alessandro.decassai@aopd.veneto.it

Alessandro De Cassai, Federico Longhini, and Stefano Romagnoli equally contributed.

Giorgio Conti and Paolo Navalesi equally contributed.

${ }^{1}$ Anesthesia and Intensive Care Unit, University Hospital of Padua, Via

Giustiniani 1, 35127 Padua, Italy

Full list of author information is available at the end of the article
}

towards containing the diffusion of the virus; on January 13th, the first case reported outside of China was reported in Thailand. COVID-19 spread early in Italy too, with two Chinese tourists resulting positive to the virus on 31 January 2020 in Rome. On February 28th, WHO declared the global emergency risk level as "very high". On March 12th, the global coronavirus disease-19 (COVID-19), the SARS-CoV-2-related infectious disease outbreak, was declared a pandemic.

A global effort of both the scientific community and governments has been undertaken to stem the pandemic. Several countries have swiftly adopted prevention and control measures to reduce the spread of COVID19 transmission (e.g. physical distancing, staying at home recommendations and even lockdown) and the scientific

(c) The Author(s). 2021 Open Access This article is licensed under a Creative Commons Attribution 4.0 International License, which permits use, sharing, adaptation, distribution and reproduction in any medium or format, as long as you give appropriate credit to the original author(s) and the source, provide a link to the Creative Commons licence, and indicate if changes were made. The images or other third party material in this article are included in the article's Creative Commons licence, unless indicated otherwise in a credit line to the material. If material is not included in the article's Creative Commons licence and your intended use is not permitted by statutory regulation or exceeds the permitted use, you will need to obtain permission directly from the copyright holder. To view a copy of this licence, visit http://creativecommons.org/licenses/by/4.0/. 
community, in a race against the clock, tried to identify, propose and validate the most effective treatments for COVID-19. In this urge to retrieve an answer for the pandemic the early body of peer-reviewed COVID-19 literature was composed primarily of case series, observational studies and experts' opinion, with randomized controlled trials lagging. The aim of this paper is to review the Italian contribution to the scientific literature regarding intensive care management of patients suffering from COVID-19, being one of the first western countries to face an outbreak of SARS-CoV-2 infection (Fig. 1).

\section{Main text}

\section{Methods}

A review protocol was written and agreed by all the authors before conducting this study.

The bibliographic search was conducted on June 23th, 2021, by one of the authors (ADC). In this review we included articles indexed by SCOPUS using the following string: "AFFILCOUNTRY (Italy) AND (TITLE-ABS-KEY(covid) OR TITLE-ABS-KEY (sars-cov-2)) AND (TITLE-ABSKEY (ICU OR "intensive care")) AND PUBYEAR > 2018 AND NOT (TITLE-ABS-KEY ("case report")) AND (LIMITTO (DOCTYPE, "ar") OR LIMIT-TO (DOCTYPE, "re"))".

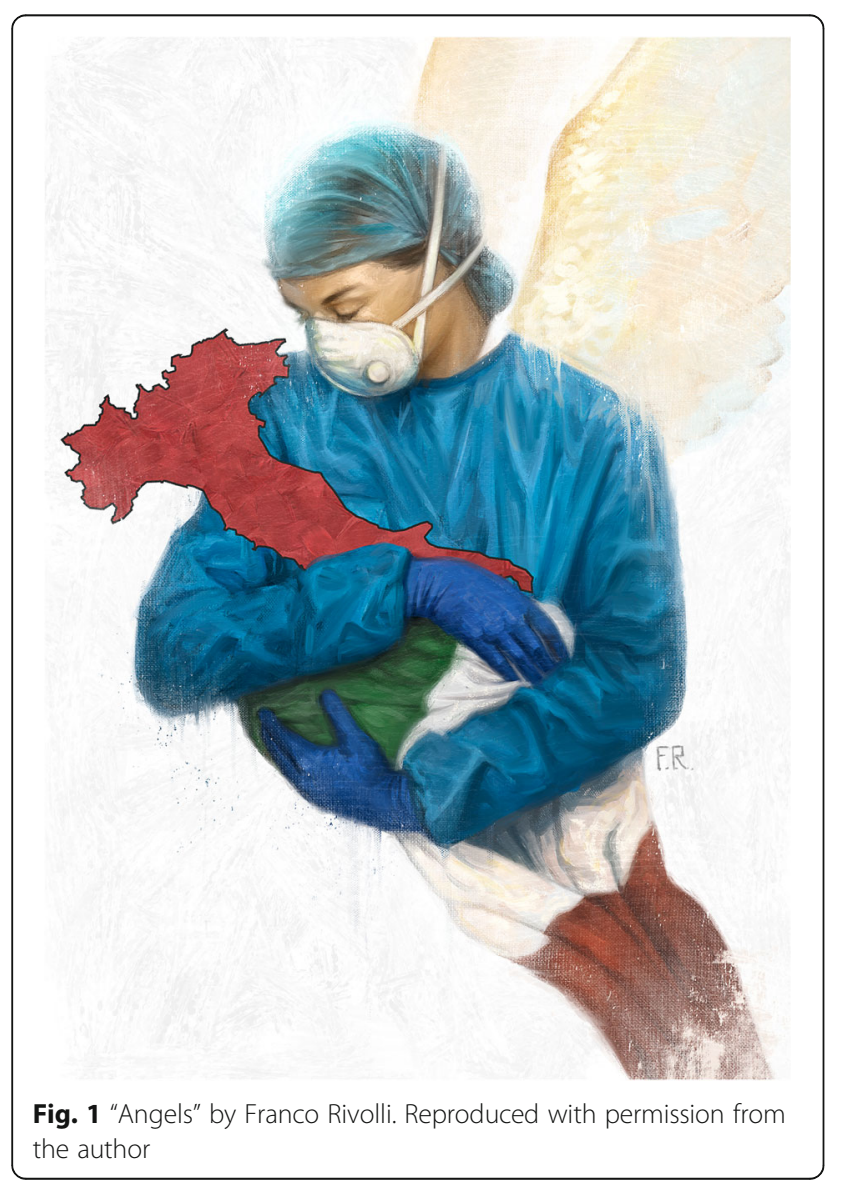

Abstracts of the identified papers were screened to remove papers not concerning the SARS-CoV-2 topic; then the list of the remaining titles was reviewed with full-text retrieval for each paper. We included the papers regarding the SARS-CoV-2 pandemic, having an Italian corresponding author and investigating any aspect of intensive care unit (ICU) management, and we excluded all the papers related to pediatrics.

\section{Ventilatory support}

SARS-CoV-2 infection is frequently complicated by hypoxemic acute respiratory failure (ARF), requiring oxygen supply and mechanical ventilation. Although considered a condition of acute respiratory distress syndrome (ARDS), COVID-19 is characterized by peculiar pathophysiological features with heterogeneous gas exchange and respiratory mechanics [2-4]. Severe hypoxemia might be related not only to loss of aeration and alveolar derecruitment but also to a disrupted ventilation/perfusion relationship [2]. Therefore, ventilator settings, including positive end-expiratory pressure (PEEP), should be personalized based on the patient's conditions, and underlying vascular derangement [5].

The latest guidelines suggest oxygen supplement when $\mathrm{SpO}_{2}$ is $<92 \%$ to maintain a $\mathrm{SpO}_{2}$ below 96\% [6]. In case of persisting hypoxemia, high-flow oxygen through nasal cannula (HFNC) is suggested over non-invasive ventilation (NIV), due to a reduced risk of intubation [6]. Of note, in critically ill patients with moderate-to-severe ARF, NIV through helmet has been shown to reduce the need for invasive mechanical ventilation (iMV), as compared to HFNC [7]. Therefore, an early trial with helmet NIV could be reasonable, though the evidence is weak. NIV application is also feasible outside the ICU to cope with the massive demand of ventilatory assistance [8]. However, close monitoring of respiratory function remains fundamental to not delay intubation, whenever needed [6]. In fact, it is known that in patients with hypoxemic ARF, intubation delay increases mortality. In patients receiving HFNC, the ROX index (pulse oximetry/ fraction of inspired oxygen/respiratory rate) may help the clinician to early detect treatment failure, even outside the ICU [7]. After $12 \mathrm{~h}$ of HFNC, a ROX-index < 5.99 is associated with an increased risk of iMV in COVID-19 patients [7].

When iMV is instituted, it is recommended a protective ventilation strategy, consisting of a low tidal volume (4-8 $\mathrm{mL} / \mathrm{kg}$ of predicted body weight), a plateau pressures $<30 \mathrm{~cm} \mathrm{H}_{2} \mathrm{O}$ and a driving pressure $<15 \mathrm{cmH}_{2} \mathrm{O}$ [6]. As mentioned above, PEEP selection should be individualized based on the lung conditions and respiratory mechanics $[2,5]$. Computed tomography (CT) scan findings, together with respiratory mechanics, may also help 
the clinician to set the best PEEP, avoiding too high values which could be harmful $[9,10]$.

Despite the application of a protective ventilation strategy, air leak from the alveoli into the pleural cavity (pneumothorax) or mediastinum (pneumomediastinum) occurs frequently, and it is associated with increased mortality. Among reasons for pneumothorax and pneumomediastinum, the high inspiratory effort of COVID-19 patients plays a major role. The so-called patient selfinflicted lung injury produces high tidal volumes and high transpulmonary pressure, causing subtle damages which will become evident during NIV or iMV $[4,11,12]$.

In case of persistent hypoxemia despite the optimization of ventilator settings, recruitment manoeuvres are suggested. Recruitment manoeuvres aim to open atelectatic alveoli and to improve oxygenation. However, recruitment manoeuvres expose the risk of barotrauma and transient hypotension [6]. Recruitment manoeuvres should not be performed using a staircase (incremental PEEP) strategy, and they are indicated only in patients with low lung compliance $[2-5,9,10]$.

In mechanically ventilated patients affected by moderate-to-severe COVID-19 ARDS, prone positioning is also suggested for a 12- to 16-h session [6]. By redistributing pulmonary blood flow and reducing atelectasis (identifiable as loss of aerated areas on chest CT), Prone positioning improves oxygenation, reduces mortality, though an increased risk for pressure sores is present $[9$, 10]. Sustained oxygenation improvement after the first prone positioning session is independently associated with improved survival and it reduces the duration of iMV [13, 14]. It has been also proposed to prolong prone positioning sessions up to $36 \mathrm{~h}$, since this is feasible and safe, it provides organizational advantages by reducing the number of prone positioning cycles for a single patient, and oxygenation improvement seems to be higher [15].

PP has been also proposed as an early strategy to improve gas exchange and reduce the risk for iMV in awake patients during HFNC and NIV [16-21]. However, data are conflicting: although no difference in the intubation rate has been shown between responders and non-responders [20], a retrospective multicenter cohort study suggests that PP can reduce the need for iMV when applied to patients receiving HFNC, but not in those with NIV support [18]. In addition, in patients undergoing NIV, awake PP improves gas exchange at the expenses of an increased diaphragm activation and worsening of the comfort [20]. NIV can also be successfully used to facilitate weaning from iMV. As compared to conventional weaning strategies, an early extubation with NIV application reduces the time spent under iMV, extubation failure rate and number of reintubation. No differences were found between strategies with respect to rate of tracheostomy, ICU mortality and length of stay [22]
In moderate-to-severe COVID-19 ARDS undergoing $\mathrm{iMV}$, the use of neuromuscular blocking agents is also suggested to facilitate the protective ventilation strategy, preferring whenever possible intermittent dosing over continuous infusion [6].

Inhaled nitric oxide can be also considered as a rescue strategy in mechanically ventilated patients with severe ARDS; however, if no rapid improvement in oxygenation is observed, the treatment should be tapered off [6]. In patients with elevated lung compliance, inhaled nitric oxide may potentially improve oxygenation by acting on lung perfusion but no data are available from this population [9]. Its usefulness is more appropriate in case of pulmonary hypertension [10].

\section{Chest imaging}

Chest imaging plays a crucial role in the diagnosis and in the follow-up/management of patients with COVID19 pneumonia.

Although the gold standard is the CT scan, the need to transfer unstable COVID-19 patients to the radiology department, the risk of viral spread and the high costs limit the applicability of this technique. In this scenario, bedside imaging techniques, such as portable chest Xray (CXR), and lung ultrasound (LUS) could be alternatives in varying conditions and for different aims.

\section{Chest X-ray}

The American College of Radiology pointed out that the use of CT scan may disrupt radiological service availability due to the CT room decontamination [23], Therefore, diagnostic algorithms have been proposed for CXR, as a first-line triage tool, in patients with clinical suspicion and waiting for results of nasopharyngeal swabs $[23,24]$. CXR is also suggested in the routine follow-up to obviate the need for CT [24].

However, in COVID-19 patients, findings may be nihil in the first days of disease. Ten to twelve days after the onset of symptoms, CXR can detect bilateral ground glass or patchy opacities, uncommonly associated with pleural fluid [23, 25]. Indeed, sensitivity is quite heterogeneous, ranging from 33 to $84 \%$, according to the timing and disease severity [25]. The application of artificial intelligence (AI) to CXR at admission allows to compute radiological scores predicting critical disease and mortality. In particular, a Qure AI score $\geq 30$ or a Radiographic Assessment of Lung Edema score $\geq 12$ on the CXR at presentation are independent and comparable predictors of adverse outcomes [26]. The semi-quantitative CXR score (ranging from 0 to 18 ) has been also proposed in a preliminary study to describe the disease severity [27].

Advantages of CXR are the low cost, the bedside availability with a dedicated portable CXR machine and the reduction of the risk of virus spread related to patient's 
transport, while the major limitations are the low sensibility and the low correlation between radiological findings and disease progression [24].

\section{CT scan}

The role of CT for the diagnosis of COVID-19 interstitial pneumonia is well established. CT scan is more sensitive and specific than CXR; it can identify interstitial involvement of lung parenchyma, even in the early stage of the disease [25]. Typical features on chest CT are groundglass opacities (with a prevalence between 46 to 100\%) and consolidation (in the later stages of the disease), frequently associated with other ancillary findings $[25,28$, 29]. Furthermore, CT scan can highlight the involvement of the lung vascular system, as well as common vascular events other than pulmonary embolism [30]. CT scan is indicated for COVID-19 patients presenting with moderate to severe clinical features and to identify worsening of lung disease [29]. Noteworthy, the extension of lung involvement, as assessed by the quantitative Pulmonary Involvement score, can predict the disease worsening, ICU admission and patients' mortality [31].

\section{Lung ultrasound}

LUS is a widely used bedside imaging technique to explore pleura and the entire lung parenchyma, following a 12-zone scanning protocol [24].

Ground glass opacities and reticular pattern on CT scan are represented by bilateral, irregularly distributed B-lines with spared areas (B-1 pattern) and coalescent Blines (B-2 pattern) at LUS. Along disease progression, subpleural consolidations increase, as identified by anechoic hemispheric areas close to the pleural line with a hyperechogenic base. Extensive consolidations appear at LUS as consolidation with hepatization of lung tissue and air bronchogram (C pattern) [23, 25, 32-34]. LUS score (as computed by the sum of scores for each parenchyma area according to the findings) is increased at ICU admission, but remains elevated at ICU discharge [32]. In addition, LUS score at admission and $72 \mathrm{~h}$ after hospital admission are reliable prognostic tools for worsening of respiratory failure and need for continuous positive airway pressure (the former) [32, 35], need for ICU admission and risk of death (the latter) [35]. Lung and cardiac combined ultrasounds are also useful to monitor the disease progression and to identify parameters (LUS score and right ventricle/left ventricle ratio) to stratify the risk of death [36]. LUS has been also suggested in integrated extubation protocols, to monitor lung aeration before and after extubation, and to predict extubation failure [37].

LUS has the advantage of bedside serial monitoring, to reduce the risk of cross-infection and virus spread related to patients' transport [24] and the number of CXRs and CT scans [38]. Disadvantages are that LUS is operator-dependent and time-consuming, needs operator experience to generate high-quality and reproducible images and does not detect abnormalities affecting the central regions surrounded by aerated lung $[23,24]$.

\section{Biomarkers}

Biomarkers can be intended as almost any measurement reflecting an interaction between a biological system and a potential hazard, which may be chemical, physical, or biological. The measured response may be functional and physiological, biochemical at the cellular level, or a molecular interaction as defined by WHO. In a new unknown disease such as COVID-19 the study of biomarkers has shown to be extremely useful for understanding the physiopathology of the infection, identifying the prognostic factors and addressing the therapeutic strategies.

\section{Vitamin $D$}

25-Hydroxyvitamin D (25OHD) has been, from the early moments, a strongly debated protagonist among the variety of biomarkers associated with SARS-CoV-2 infection. Its known modulatory role in both innate and adaptive immunity, including the downregulation of inflammatory cytokines such as interleukin-6 (IL-6), together with the observation of its protective capability for infections of the respiratory tract, have led to several studies regarding this molecule. Even though a univocal conclusion has not been reached, it has been shown that circulating levels of 25OHD were lower in severely symptomatic COVID-19 patients than in mildly symptomatic subjects [39]. Such studies made it possible to identify 25OHD as a plausible independent prognostic factor and open the way to further studies on the effects of supplementation with vitamin D in deficient individuals.

\section{Coagulation}

The severe phenotype of SARS-CoV-2 infection is frequently associated with elevated D-dimer [40] low platelet count [41], together with elevated von Willebrand factor and higher agglutination rates induced by ristocetin [42]. These features are strongly suggestive of systemic clotting activation and enhanced agglutination, with secondary fibrinolysis and thrombocytes consumption. These findings have demonstrated to have important consequences both from the prognostic point of view, being elevated $\mathrm{D}$-dimer and low platelets associated with a worse prognosis, and the therapeutic one, since prophylaxis with low molecular weight heparin has resulted in better outcomes and higher survival rates $[40,41]$. 


\section{Inflammation}

IL-6 is a pleiotropic, proinflammatory, multifunctional cytokine released by different types of cells, including macrophages, adipocytes and blood cells. Produced during inflammatory processes, IL-6 is also fundamental for production of another important biomarker such as Creactive protein, so the two molecules are strongly linked.

IL-6 can be considered an early biomarker in the prediction of clinical deterioration of patients with moderate-tosevere COVID-19, especially when associated with other biochemical and physiological parameters such as $\mathrm{SpO}_{2} /$ $\mathrm{FiO}_{2}$ ratio and C-reactive protein itself [43]. Moreover, playing such a pivotal role in the pathogenesis of moderate-to-severe SARS-CoV-2 infection, IL-6 can also represent an important target for therapeutic strategies involving monoclonal antibodies (i.e. Tocilizumab) [44-46].

C-reactive protein, as mentioned before, has also shown increased levels during SARS-CoV-2 infection and higher values have appeared to be strongly associated with a higher risk of ICU transfer [47, 48].

Moreover, procalcitonin has also emerged to be an adverse outcome index, especially in ICU, when its elevated values can be also correlated to bacterial superinfection [40].

\section{White blood cells}

Leucocytes show a peculiar pattern in moderate-tosevere infection from SARS-CoV-2. This pattern is characterized by leukocytosis accompanied by a major increase in neutrophils count [49] and a relevant lymphopenia [44, 50].

Neutrophilia can be explained by the severe Systemic Inflammatory Response Syndrome and the cytokines storm that accompany ICU patients, but also by potential superinfections $[49,51]$. On the other hand, the decrease of lymphocytes count can find an explanation in the numerous data suggesting tissue sequestration (especially in lungs, lymphoid tissues and GI tract) and destruction in peripheral blood, due to the prevalence of a senescent phenotype of $B$ cells, $T$ cells and natural killer-NK $[44,51]$.

An important implication of this specific pattern is the possibility to use a particular parameter, the neutrophilto-lymphocytes ratio, as an independent predictor of severe COVID-19 cases that require ICU admission [51].

\section{Organ damage}

Firstly, liver enzymes have proved to be frequently elevated in severe SARS-CoV-2 infection. Whether this is due to direct or hypoxic damage is not clear, but elevation of liver enzymes has shown association with poorer outcome [52]. Heart damage has also appeared to be a common laboratory finding: approximately $50 \%$ of patients have elevated cardiac biomarkers at admission and elevation of both highly sensitive troponin-I (hsTnI) e brain natriuretic peptide (BNP) has appeared to be a strong independent predictor of mortality [53]. Ultimately, lactate arterial-venous gradient is a parameter that has emerged to be a valid biomarker of lung damage, especially in mechanically ventilated patients. An augmented gradient, in fact, has appeared to be an expression of lung inflammation and can be a useful monitoring tool [49].

\section{Pharmacological interventions}

Despite an increase in knowledge over SARS-COV-2 and global efforts to identify interventions for the prevention and treatment of COVID-19, there is evidence for effective treatment protocols. Interesting possibilities are emerging thanks to the use of drugs that were originally developed for other clinical indications, whose pharmacological profiles suggest an impact on some of the multiple pathophysiological aspects of COVID-19 illness.

\section{Low-molecular-weight heparin}

Patients with SARS-COV-2 infection have a high risk to develop venous thrombotic events [54] and since the beginning of the pandemic, the WHO has recommended antithrombotic prophylaxis with low molecular weight heparin to reduce the venous thromboembolism risk.

A prospective study including 264 patients who did not require ventilation has shown that prophylaxis significantly and independently reduced mortality [55].

High mortality in ICUs, data from autopsies of ICU patients indicated pulmonary embolism as a frequent fatal event. The observation of several risk factors for deep vein thrombosis in patients hospitalized with COVID-19 prompted some ICUs to increase the prophylactic dose of enoxaparin from $40 \mathrm{mg}$ daily up to $1 \mathrm{mg} / \mathrm{kg}$ twice daily. Results show that patients receiving high doses of enoxaparin have reduced mortality, clinical deterioration and venous thromboembolism by approximately $50-60 \%$ compared to patients on standard doses [56]. The optimal prophylactic enoxaparin dose is still debated.

It is still not clear which are the best tests to monitor and guide anticoagulation in acutely ill patients, Anti-Xa seems a more reliable method to monitor heparin treatment in acute patients [57].

\section{Corticosteroid}

The efficacy and safety of corticosteroids in patients with SARS-COV-2 infection are still debated. An observational prospective study on patients admitted for COVID-19 who did not receive iMV shows that treatment with corticosteroids is not associated with a reduction of in-hospital mortality; although within the 
subgroup of COVID-19 patients treated with NIV, corticosteroid therapy is associated with a lower odds ratio for ICU admission [58, 59]. According to this multicenter observational study, early administration of prolonged, low dose methylprednisolone treatment in patients with severe COVID-19 pneumonia was associated with a significantly lower risk of death and decreased ventilator dependence. Methylprednisolone treatment was demonstrated to be safe and also allowed for a significant decrease in mortality and an immediate improvement in systemic inflammation and oxygenation markers, as well as a reduction of iMV length [60].

A Meta-Analysis of randomized controlled trials shows that corticosteroids may be considered in critically ill patients with COVID-19 but must be discouraged in patients not requiring oxygen therapy: it appears that spontaneously breathing patients treated with corticosteroids had less requirement for iMV, but higher mortality rate than patients who did not receive corticosteroids [61].

\section{Tocilizumab}

Tocilizumab has become one of the therapeutic options for the management of cytokine release syndrome, a condition that seems to be present also in patients hospitalized with respiratory failure due to COVID-19, therefore it was hypothesized that tocilizumab could be clinically effective for this population. So far, the experience with tocilizumab in COVID-19 patients is limited and studies show different results due to a lack of a standardized therapeutic scheme, short post-treatment follow-up and the absence of a comparison group. This retrospective cohort study did not show a clear improvement in patients receiving tocilizumab compared to standard management [62] although other studies including severe COVID-19 patients admitted to ICU seem to show an improvement in their clinical status and the need for iMV [63, 64].

\section{Remdesivir}

Remdesivir treatment seems to have a beneficial effect on SARS-CoV-2 pneumonia, especially in the case of non-critically ill patients [65]. Remdesivir does not appear to be associated with a significant reduction of mortality in mechanically ventilated patients, but it is consistently associated with a shorter duration of iMV and higher probability of hospital discharge, independently of other risk factors [66]. Contrarily, in a different study Remdesivir appears to be associated with a significant beneficial effect on the survival of patients with COVID-19 treated with iMV [67]. Ongoing randomized controlled trials are needed to clarify its efficacy, safety, whom to treat and when.

\section{Bacterial superinfections (or secondary infections)}

Bacterial superinfections seem to play a crucial role in COVID-19 patients admitted to the ICU, acting as a key determinant of important outcomes such as ICU and hospital length of stay, duration of iMV and mortality. Current literature shows that bacterial superinfections affect a significant number of patients, although there is a wide variation in the reported incidence of this complication [68, 69]. In the light of the above findings, data on the incidence of superinfections should be interpreted and analysed with caution since most COVID-19-related studies have not included superinfections among study endpoints. Italian physicians have efficiently contributed to spread knowledge on this topic, with data reports and publications focusing on drug-resistant bacteria. In a recent review on secondary infections, Fattorini and collaborators, underlined that secondary infections significantly decreased survival of COVID-19 patients, especially if they had been admitted to the ICU [70]. De Santis and colleagues conducted a prospective observational study of critically ill patients with COVID-19 admitted to eight Italian ICUs [69]. In line with previous evidence, the authors observed that, of the 248 patients recruited, 90 (36.3\%) developed at least one episode of secondary infection. Increasing ICU length of stay was associated with a higher occurrence of infectious complications, with ventilator-associated pneumonia (VAP) being the most frequent. In patients with bacteremia and VAP, a balanced mix of Gram-negative and Gram-positive organisms was found, although polymicrobial and urinary tract infections were more frequently caused by Gram-negative microorganisms. At least one course of antibiotic therapy was given to 161 (64.9\%) patients. Logically, patients developing bacteremia had a higher risk of ICU and hospital mortality ( $45.9 \%$ vs. $31.6 \%$ and $56.8 \%$ vs. $40.3 \%$, respectively). Based on these findings, the authors concluded that regular microbiological surveillance and strict infection control measures should be implemented for the management of COVID-19 patients. A multicenter, before-and-after, cross-sectional study compared the rates of colonization and infection with carbapenemase-producing Enterobacteriaceae and/or carbapenem-resistant AcinetobacterBaumannii in two different study periods (Jan-Apr 2019 vs. Jan-Apr 2020) [71]. Interestingly, compared to period 1 , during period 2 the incidence rate ratios of colonization and infection with carbapenem-resistant Acinetobacter Baumannii increased 7.5- and 5.5-fold, respectively. Differently, no significant changes were found in carbapenemase-producing Enterobacteriaceae colonization and infection during the two study periods. Concerning the topic of multi-drug resistant (MDR) bacteria secondary infection, Pasero and collaborators performed a review of the literature to investigate the incidence of this important co-infections/superinfections [72]. According to the authors, most of the studies (mainly retrospective and single-centred) reported low rates of co-infections but a significant incidence of hospital-acquired infections 
developing about 10-15 days after ICU admission. In fact, most bacterial infections described in the COVID-19 population emerged during the ICU and hospital stay (secondary bacterial infections), with an estimated incidence of 14.3\% [70]. The reported incidence of MDR bacterial secondary infections was high (ranging between 32\% to 50\%). Pasero and colleagues suggested that prolonged ICU length of stay and extensive use of broad-spectrum antimicrobial drugs might have contributed to the selection of pathogens. Similarly, MDR infections were associated with a longer ICU stay. IMV was identified as a risk factor independently associated with MDR secondary infections. Ultimately, the authors recommended judicious prescription and management of antimicrobials according to a stewardship program. Relative to investigation strategies, Foschi and collaborators assessed respiratory bacterial co-infections in lower respiratory tract samples by comparing the conventional culture approach to an innovative molecular diagnostic technology based on multiplex PCR panel (FilmArray Pneumonia Plus panel) [73]. More than $30 \%$ of samples were culture positive for pathogens, including Pseudomonas aeruginosa, Klebsiella pneumoniae and Staphylococcus aureus. Film-Array showed an overall sensitivity and specificity of $89.6 \%$ and $98.3 \%$, respectively, with a negative predictive value of $99.7 \%$. According to the authors, the molecular test significantly reduced the turn-around-time and increased the rates of microbial detection but missed a list of pathogens not included in the molecular panel, especially Stenotrophomonas maltophilia. A retrospective study investigated possible predictive factors for bacterial VAP in a cohort of 39 COVID-19 patients who required iMV [74]. Fifty-four percent of the patients were diagnosed with bacterial VAP. Multivariate logistic regression for prediction of VAP showed significant differences in duration of ICU hospitalization and in minimal lung compliance. Additionally, $71 \%$ of the isolated germs were MDR and bacteremia was reported in 38\%. Multivariate analyses for prediction of lethality found significant differences in sequential organ failure assessment (SOFA) score. Cataldo and collaborators performed a retrospective cohort study including adult COVID-19 patients hospitalized in ICU at the National Institute for Infectious Diseases, Rome, Italy, to assess the incidence of bacterial and fungal bloodstream infections (BSIs) in COVID-19 patients [75]. Data collected in this study evidenced an exaggerated risk of acquiring bacterial and fungal BSIs among critically ill COVID-19 patients admitted to the ICU. In the pre-COVID-19 period, the prevalence of BSIs in patients staying at the same ICU was 3.8 times lower than the prevalence observed in the study. Antinori and colleagues published a review on studies reporting bacterial and fungal co-infections in patients with COVID-19 [76]. Most studies were retrospective and produced poor quality data biased with short follow-up and selection of patients. Septic shock was reported in $4 \%$ to $33.1 \%$ of patients and $71-100 \%$ of patients received antimicrobial therapy. Interestingly, the authors observed that, as previously reported in the influenza pandemic, invasive pulmonary aspergillosis seems to be an increasingly observed complication in critically ill patients with SARS-CoV-2 infection. In conclusion, hospitals managing surges of patients with COVID-19 eventually are vulnerable to outbreaks of MDR organism infections. Developing dedicated infection prevention and control best practices, to the largest extent possible, is mandatory and there is a need for careful infection control activities targeted against the spread of antimicrobial resistance.

\section{Prognosis}

The disease severity and mortality in patients with COVID-19 has been extensively studied and several variables have been investigated as independent risk-factors for worsened outcomes.

First of all, patients with cardiometabolic comorbidities are at increased risk for worsened outcomes [77]. Cerebrovascular and cardiovascular co-morbidities, chronic obstructive pulmonary disease, diabetes, hypertension, smoking and male sex are associated with severe disease and mortality [77, 78]. Newly diagnosed diabetes and admission hyperglycemia are powerful predictors of COVID-19 severity due to rapid respiratory deterioration [79]. Hyperglycemia ( $>180 \mathrm{mg} / \mathrm{dl}$ ) is more common in non-survivors showing also a significantly higher glucose variability in the first $48 \mathrm{~h}$ after ICU admission [80]. Obesity is another independent risk factor for respiratory failure, hospital admission, more severe progression of the disease requiring ICU admission and death [81, 82]. A body mass index higher than $30 \mathrm{~kg} / \mathrm{m}^{2}$ identifies a population of patients at high risk for severe illness, whereas a value higher than $35 \mathrm{~kg} / \mathrm{m}^{2}$ dramatically increases the risk of death [81]. Furthermore, the presence of visceral fat is significantly higher in patients requiring ICU admission, it is a marker of worse clinical outcomes in patients with COVID-19, as well as it prolongs the hospital and ICU lengths of stay and increases the risk of death $[83,84]$.

In the context of critically ill COVID-19 patients, lymphocytopenia, thrombocytopenia, ferritin, liver enzyme elevation, high D-dimer and lengthening of prothrombin time are strictly correlated with higher ICU and/or hospital mortality [40, 52, 85, 86].

The presence of increased procalcitonin, increased DDimer and thrombocytopenia also predict the occurrence of severe infections [41]. In addition, low serum prealbumin concentrations are significantly associated with COVID-19 severity and mortality. This combined marker of malnutrition and inflammation might assist with early risk stratification and management in this group of patients [87].

Serum sodium at admission may be considered as an early prognostic marker of disease severity in hospitalized COVID-19 patients. Patients with hyponatremia 
have a higher need for non-invasive ventilation and ICU admission than those with normonatremia or hypernatremia. Hyponatremia is also an independent predictor of in-hospital mortality, and each $\mathrm{mEq} / \mathrm{L}$ of serum sodium reduction is associated with a $14.4 \%$ increased risk of death [88].

25OHD and IL-6 levels are also associated with poorer outcomes. In particular, 25OHD and IL-6 levels are respectively lower and higher in severely symptomatic COVID-19 patients admitted to ICU, as compared to not critically ill patients, and in non-survivors as compared to survivors $[38,89]$. Hypovitaminosis D is also associated with susceptibility to respiratory infections [89].

In COVID-19 ICU-patients, mid-regional proadrenomedullin (MR-proADM) seems to have constantly higher values in non-survivors and predict mortality more precisely than other biomarkers. Repeated MR-proADM measurement may support rapid and effective decision-making $[86,90]$.

A COVID-19 in-hospital mortality risk score is a clinical risk score proposed to predict the in-hospital mortality, based on a set of variables available soon after the hospitalization. Included predictors are age, number of chronic diseases, respiratory rate, $\mathrm{PaO}_{2} / \mathrm{FiO}_{2}$, serum creatinine and platelet count. It is highly accurate in stratifying patients at low, intermediate and high risk of inhospital death [91].

Finally, in patients with septic shock, low levels of circulating immunoglobulins are common, and their kinetics appear to be related to clinical outcome. Regarding adjunctive therapy with polyclonal immunoglobulins, several studies have revealed that immunoglobulin titles are commonly low at the onset of sepsis and that during the sepsis course. Persistent low levels of immunoglobulins are closely related to increased mortality [92].

\section{Communication and relatives}

The urgent ICU admission of patients with COVID-19 is undoubtedly a stressful event with significant psychological repercussions on patients' family members. Despite the efforts made during the COVID-19 pandemic to improve communication and personal interactions among patients, relatives and healthcare workers, an incredibly high prevalence of burnout, post-traumatic, major depressive, or generalized anxiety disorders and pathological or complicated grief has been observed [93].

Several authors have critically explored how to communicate with and involve families living in complete isolation in the last years. Clinical communication in this context should provide understandable information about the disease and treatment options, obtain information on expectations and choices, show collaboration, allow relatives to express their emotions, prevent misunderstandings and conflicts with the care team. Indeed, specific technical and non-technical skills in communication are required to reach these targets. Critical importance has been recognized for the relational aptitude and the preparation of the communication, confidentiality, truth, coherence, gradualness and grief. Information on patients' clinical conditions should reach relatives at least once a day, at the same time, from a quiet and suitable place, preferably from the same doctor who knows the patient well. As the healthcare workers' mental and emotional well-being plays a key role in this process, psychological assistance should always be considered for both operators and relatives [94]. Of note, particularly in this pandemic course, the assistance to relatives should be continued during their grief [95], mainly for the restrictions in seeing, visiting, or performing funerals to the loved one.

Peculiar characteristics have also been recognized for the modalities of communication. The introduction of physical isolation measures during the SARS-CoV-2 pandemic has profoundly changed communication with relatives, almost entirely based on telephone calls. When their clinical conditions allow the patients to interact with relatives, video calls with dedicated tablets and smartphones have been applied to reduce social distances. The same technology has been applied to support the patient with external specialist consultations as psychological therapies [96]. Finally, enhanced strategies for telecommunication in the ICU have allowed the health workers to establish a more direct relationship with the families, provide them more precise information on patients' clinical condition and prognosis, encourage discussion on patients' preferences or expectations at the end-of-life and ultimately promote shared decision-making.

\section{Organization}

The unexpected and sudden increase in iMV and multiple organ support requirements in COVID-19 patients [97] has forced the hospitals to reallocate the available resources, substantially modify their infrastructures and entirely reconsider their activities [98-100]. For example, except for transplantations, oncological and undeferrable surgeries, the elective surgical procedures were almost cancelled in every Italian region [101]. Healthcare staff involved in the perioperative medicine was thus reassigned to critical care, and more beds in the postoperative ICU became available. Furthermore, the same operating theatres and anaesthesia recovery units have been reallocated as intensive care or highdependency units in many cases [102].

The increase in the ICU beds capacity was undoubtedly the priority during the COVID-19 outbreak. Accordingly, the extensive hiring campaign performed by several hospitals (made possible by the increase in funds dispatched by the national health system) has been 
addressed towards healthcare workers primarily involved in emergency and critical care.

A careful separation between COVID and non-COVID pathways was maintained to minimize the risk of inhospital SARS-CoV2 infection. In this context, creating dedicated high-dependency units and triage areas where patients with respiratory symptoms could be treated waiting for the SARS-CoV2 diagnostic tests before being assigned to a specific department was crucial to relieve ICU from the risk of overload [103, 104]. Interestingly, many hospitals had the opportunity to use buildings dedicated exclusively to COVID patients, especially during the second wave of COVID-19 infection (October 2020).

\section{Conclusions}

By the end of March 2020, Italy had the second highest number of COVID-19 infections worldwide, and the largest number of deaths. After the identification of the first severe case of COVID-19 on February 20, 2020-a young man with no history of possible exposure abroad, diagnosed with COVID-19 in Codogno, Lombardy-the outbreak rampaged through various areas of northern Italy. Within 2 weeks, an exponential increase in new cases of COVID-19, including many critically ill patients, was reported in the surrounding areas, and new clusters were identified in the nearby regions of Piedmont and Veneto. Since then, COVID-19 infection has spread throughout the country with a somewhat lower impact from north to south. The Italian anaesthesiologists/intensivists, nurses and many other professionals and institutions (e.g. engineers, companies) faced something never seen before. This review of the literature is dedicated to all of them that with invaluable courage, dedication, efforts and sacrifice have dedicated their professional life to thousands of patients. Many colleagues, nurses and patients died leaving their families alone. To all of them, we send our thoughts and dedicate these pages.

\section{Abbreviations \\ 25OHD: 25-Hydroxyvitamin D; ARDS: Acute respiratory distress syndrome; ARF: Acute respiratory failure; CXR: Chest X-ray; CT: Computed tomography; COVID-19: Coronavirus disease-19; HFNC: High-flow oxygen through nasal cannula; ICU: Intensive care unit; IL-6: Interleukin-6; iMV: Invasive mechanical ventilation; LUS: Lung ultrasound; MR-proADM: Mid-regional pro- adrenomedullin; MDR: Multi-drug resistant; NIV: Non-invasive ventilation; PEEP: Positive end-expiratory pressure; SARS-CoV-2: Severe acute respiratory syndrome coronavirus-2; VAP: Ventilator-associated pneumonia}

\section{Authors' contributions}

Study conception: PN, GC; Study design: ADC, FL, SR; Research proposal: PN, GC; Data collection: All the authors; Writing of paper: All the authors; Editing of paper: All the authors. The authors read and approved the final manuscript.

\section{Availability of data and materials}

Data sharing is not applicable to this article as no datasets were generated or analysed during the current study.

\section{Declarations}

Ethics approval and consent to participate

Not applicable

\section{Consent for publication}

Not applicable

\section{Competing interests}

The authors declare that they have no competing interests.

\section{Author details}

${ }^{1}$ Anesthesia and Intensive Care Unit, University Hospital of Padua, Via Giustiniani 1, 35127 Padua, Italy. ${ }^{2}$ Anesthesia and Intensive Care, "Mater Domini" University Hospital, Department of Medical and Surgical Sciences, "Magna Graecia" University, Catanzaro, Italy. ${ }^{3}$ Department of Health Science, Section of Anaesthesia and Critical Care, University of Florence, Florence, Italy. ${ }^{4}$ Department of Anaesthesia and Critical Care, Azienda Ospedaliero-Universitaria Careggi, Florence, Italy. ${ }^{5}$ Department of Medicine-DIMED, University of Padua, Padua, Italy. ${ }^{6}$ Department of Anesthesia and Intensive Care, Fondazione Policlinico A. Gemelli IRCCS, Rome, Italy.

Received: 13 October 2021 Accepted: 28 October 2021

Published online: 17 November 2021

\section{References}

1. World Health Organization (WHO) (2021) Coronavirus disease (COVID-19) pandemic. [cited August 29, 2021]; Available from: https://www.who.int/ emergencies/diseases/novel-coronavirus-2019

2. Ball L, Robba C, Maiello L, Herrmann J, Gerard SE, Xin Y, Battaglini D, Brunetti I, Minetti G, Seitun S, Vena A, Giacobbe DR, Bassetti M, Rocco PRM, Cereda M, Castellan L, Patroniti N, Pelosi P (2021) Computed tomography assessment of PEEP-induced alveolar recruitment in patients with severe COVID-19 pneumonia. Crit Care 25(1):81. https://doi.org/10.1186/s13054-02103477-w

3. Grasselli G, Cattaneo E, Florio G, Ippolito M, Zanella A, Cortegiani A, Huang J, Pesenti A, Einav S (2021) Mechanical ventilation parameters in critically ill COVID-19 patients: a scoping review. Crit Care 25(1):115. https://doi.org/1 0.1186/s13054-021-03536-2

4. Grieco DL, Bongiovanni F, Chen L, Menga LS, Cutuli SL, Pintaudi G, Carelli S, Michi T, Torrini F, Lombardi G, Anzellotti GM, De Pascale G, Urbani A, Bocci MG, Tanzarella ES, Bello G, Dell'Anna AM, Maggiore SM, Brochard L, Antonelli M (2021) Respiratory physiology of COVID-19-induced respiratory failure compared to ARDS of other etiologies. Crit Care 24(1):529. https://doi. org/10.1186/s13054-020-03253-2

5. Foti G, Giannini A, Bottino N, Castelli GP, Cecconi M, Grasselli G, Guatteri L, Latronico N, Langer T, Monti G, Muttini S, Pesenti A, Radrizzani D, Ranucci M, Russotto V, Fumagalli R (2021) Management of critically ill patients with COVID-19: suggestions and instructions from the coordination of intensive care units of Lombardy. Minerva Anestesiol 86:1234-1245

6. Alhazzani W, Moller MH, Arabi YM, Loeb M, Gong MN, Fan E, Oczkowski S, Levy MM, Derde L, Dzierba A, Du B, Aboodi M, Wunsch H, Cecconi M, Koh Y, Chertow DS, Maitland K, Alshamsi F, Belley-Cote E, Greco M, Laundy M, Morgan JS, Kesecioglu J, McGeer A, Mermel L, Mammen MJ, Alexander PE, Arrington A, Centofanti JE, Citerio G, Baw B, Memish ZA, Hammond N, Hayden FG, Evans L, Rhodes A (2021) Surviving Sepsis Campaign: guidelines on the management of critically ill adults with coronavirus disease 2019 (COVID-19). Intensive Care Med 46(5):854-887. https://doi.org/10.1007/ s00134-020-06022-5

7. Vega ML, Dongilli R, Olaizola G, Colaianni N, Sayat MC, Pisani L, Romagnoli M, Spoladore G, Prediletto I, Montiel G, Nava S (2021) COVID-19 pneumonia and ROX index: time to set a new threshold for patients admitted outside the ICU. Authors' reply. Pulmonology 27(5):475-476. https://doi.org/10.1016/ j.pulmoe.2021.07.001

8. Cammarota G, Esposito T, Azzolina D, Cosentini R, Menzella F, Aliberti S, Coppadoro A, Bellani G, Foti G, Grasselli G, Cecconi M, Pesenti A, Vitacca M, Lawton T, Ranieri VM, Di Domenico SL, Resta O, Gidaro A, Potalivo A, Nardi G, Brusasco C, Tesoro S, Navalesi P, Vaschetto R, De Robertis E (2021) Noninvasive respiratory support outside the intensive care unit for acute respiratory failure related to coronavirus-19 disease: 
a systematic review and meta-analysis. Crit Care 30(1):268. https://doi. org/10.1186/s13054-021-03697-0

9. Robba C, Battaglini D, Ball L, Patroniti N, Loconte M, Brunetti I, Vena A, Giacobbe DR, Bassetti M, Rocco PRM, Pelosi P (2020) Distinct phenotypes require distinct respiratory management strategies in severe COVID-19. Respir Physiol Neurobiol 279:103455. https://doi.org/10.1016/j.resp.2020.103455

10. Gattinoni L, Chiumello D, Rossi S (2020) COVID-19 pneumonia: ARDS or not? Crit Care 24(1):154. https://doi.org/10.1186/s13054-020-02880-z

11. Protti A, Greco M, Filippini M, Vilardo AM, Langer T, Villa M, Frutos-Vivar F, Santini A, Caruso PF, Spano S, Anzueto A, Citerio G, Bellani G, Foti G, Fumagalli R, Pesenti A, Grasselli G, Cecconi M (2021) Barotrauma in mechanically ventilated patients with Coronavirus disease 2019: a survey of 38 hospitals in Lombardy, Italy. Minerva Anestesiol 87(2):193-198. https:// doi.org/10.23736/S0375-9393.20.15002-8

12. Belletti A, Palumbo D, Zangrillo A, Fominskiy EV, Franchini S, Dell'Acqua A, Marinosci A, Monti G, Vitali G, Colombo S, Guazzarotti G, Lembo R, Maimeri N, Faustini C, Pennella R, Mushtaq J, Landoni G, Scandroglio AM, Dagna L, De Cobelli $F$ (2021) Predictors of pneumothorax/pneumomediastinum in mechanically ventilated COVID-19 patients J Cardiothorac Vasc Anesth (In press)

13. Scaramuzzo G, Gamberini L, Tonetti T, Zani G, Ottaviani I, Mazzoli CA, Capozzi C, Giampalma E, Bacchi Reggiani ML, Bertellini E, Castelli A, Cavalli I, Colombo D, Crimaldi F, Damiani F, Fusari M, Gamberini E, Gordini G, Laici C, Lanza MC, Leo M, Marudi A, Nardi G, Papa R, Potalivo A, Russo E, Taddei S, Consales G, Cappellini I, Ranieri VM, Volta CA, Guerin C, Spadaro S (2021) Sustained oxygenation improvement after first prone positioning is associated with liberation from mechanical ventilation and mortality in critically ill COVID-19 patients: a cohort study. Ann Intensive Care 11(1):63. https://doi.org/10.1186/s13613-021-00853-1

14. Langer T, Brioni M, Guzzardella A, Carlesso E, Cabrini L, Castelli G, Dalla Corte F, De Robertis E, Favarato M, Forastieri A, Forlini C, Girardis M, Grieco DL, Mirabella L, Noseda V, Previtali P, Protti A, Rona R, Tardini F, Tonetti T, Zannoni F, Antonelli M, Foti G, Ranieri M, Pesenti A, Fumagalli R, Grasselli G (2021) Prone position in intubated, mechanically ventilated patients with COVID-19: a multi-centric study of more than 1000 patients. Crit Care 25(1): 128. https://doi.org/10.1186/s13054-021-03552-2

15. Carsetti A, Damia Paciarini A, Marini B, Pantanetti S, Adrario E, Donati A (2020) Prolonged prone position ventilation for SARS-CoV-2 patients is feasible and effective. Crit Care 24(1):225. https://doi.org/10.1186/s13054-02 0-02956-w

16. Tonelli R, Pisani L, Tabbi L, Comellini V, Prediletto I, Fantini R, Marchioni A, Andrisani D, Gozzi F, Bruzzi G, Manicardi L, Busani S, Mussini C, Castaniere I, Bassi I, Carpano M, Tagariello F, Corsi G, d'Amico R, Girardis M, Nava S, Clini E (2020) Early awake proning in critical and severe COVID-19 patients undergoing noninvasive respiratory support: A retrospective multicenter cohort study. Pulmonology. (In press),

17. Simioli F, Annunziata A, Langella G, Martino M, Musella S, Fiorentino (2021) Early prone positioning and non-invasive ventilation in a critical COVID-19 subset. A single centre experience in Southern Italy. Turk Thorac J 22(1):5761. https://doi.org/10.5152/TurkThoracJ.2021.20158

18. Coppo A, Bellani G, Winterton D, Di Pierro M, Soria A, Faverio P, Cairo M, Mori S, Messinesi G, Contro E, Bonfanti P, Benini A, Valsecchi MG, Antolini L, Foti G (2020) Feasibility and physiological effects of prone positioning in non-intubated patients with acute respiratory failure due to COVID-19 (PRON-COVID): a prospective cohort study. Lancet Respir Med 8(8):765-774. https://doi.org/10.1016/S2213-2600(20)30268-X

19. Paternoster G, Sartini C, Pennacchio E, Lisanti F, Landoni G, Cabrini L (2020) Awake pronation with helmet continuous positive airway pressure for COVID-19 acute respiratory distress syndrome patients outside the ICU: a case series. Med Intensiva (Engl Ed) (In press).

20. Cammarota G, Rossi E, Vitali L, Simonte R, Sannipoli T, Anniciello F, Vetrugno L, Bignami E, Becattini C, Tesoro S, Azzolina D, Giacomucci A, Navalesi P, De Robertis E (2021) Effect of awake prone position on diaphragmatic thickening fraction in patients assisted by noninvasive ventilation for hypoxemic acute respiratory failure related to novel coronavirus disease. Crit Care 25(1):305. https://doi.org/10.1186/s13054-021-03735-x

21. Longhini F, Bruni A, Garofalo E, Navalesi P, Grasselli G, Cosentini R, Foti G, Mattei A, Ippolito M, Accurso G, Vitale F, Cortegiani A, Gregoretti C (2020) Helmet continuous positive airway pressure and prone positioning: a proposal for an early management of COVID-19 patients. Pulmonology 26(4):186-191. https://doi.org/10.1016/j.pulmoe.2020.04.014
22. Cammarota G, Vaschetto R, Azzolina D, De Vita N, Olivieri C, Ronco C, Longhini F, Bruni A, Colombo D, Pissaia C, Prato F, Maestrone C, Maestrone M, Vetrugno L, Bove T, Lemut F, Taretto E, Locatelli A, Barzaghi N, Cerrano M, Ravera E, Zanza C, Selva AD, Blangetti I, Salvo F, Racca F, Longhitano Y, Boscolo A, Sguazzotti I, Bonato V, Grossi F, Crimaldi F, Perucca R, Boniolo E, Verdina F, Vignazia GL, Santangelo E, Tarquini R, Zanoni M, Messina A, Marin M, Bacigalupo P, Sileci G, Sella N, De Robertis E, Corte FD, Navalesi P (2021) Early extubation with immediate non-invasive ventilation versus standard weaning in intubated patients for coronavirus disease 2019: a retrospective multicenter study. Sci Rep 11(1):13418. https://doi.org/10.1038/s41598-02192960-z

23. Agricola E, Beneduce A, Esposito A, Ingallina G, Palumbo D, Palmisano A, Ancona F, Baldetti L, Pagnesi M, Melisurgo G, Zangrillo A, De Cobelli F (2020) Heart and lung multimodality imaging in COVID-19. JACC CardiovasC Imaging 13(8):1792-1808. https://doi.org/10.1016/j.jcmg.2020.05.017

24. Floridi C, Fogante M, Agostini A, Borgheresi A, Cellina M, Natella R, Bruno F, Cozzi D, Maggialetti N, Palumbo P, Miele V, Carotti M, Giovagnoni A (2020) Radiological diagnosis of coronavirus disease 2019 (COVID-19): a Practical Guide. Acta Biomed 91(8-S):51-59. https://doi.org/10.23750/abm.v91 i8-S.9973

25. Campagnano S, Angelini F, Fonsi GB, Novelli S, Drudi FM. (2021) Diagnostic imaging in COVID-19 pneumonia: a literature review. J Ultrasound (In press).

26. Mushtaq J, Pennella R, Lavalle S, Colarieti A, Steidler S, Martinenghi CMA, Palumbo D, Esposito A, Rovere-Querini P, Tresoldi M, Landoni G, Ciceri F, Zangrillo A, De Cobelli F (2021) Initial chest radiographs and artificial intelligence (Al) predict clinical outcomes in COVID-19 patients: analysis of 697 Italian patients. Eur Radiol 31(3):1770-1779. https://doi.org/10.1007/ s00330-020-07269-8

27. Borghesi A, Maroldi R (2020) COVID-19 outbreak in Italy: experimental chest $X$-ray scoring system for quantifying and monitoring disease progression. Radiol Med 125(5):509-513. https://doi.org/10.1007/s11547-020-01200-3

28. Silva M, Ledda RE, Schiebler M, Balbi M, Sironi S, Milone F, Affanni $P$, Milanese G, Sverzellati N (2021) Frequency and characterization of ancillary chest CT findings in COVID-19 pneumonia. Br J Radiol 94(1118):20200716. https://doi.org/10.1259/bjr.20200716

29. Vernuccio F, Giambelluca D, Cannella R, Lombardo FP, Panzuto F, Midiri M, Cabassa P (2020) Radiographic and chest CT imaging presentation and follow-up of COVID-19 pneumonia: a multicenter experience from an endemic area. Emerg Radiol 27(6):623-632. https://doi.org/10.1007/s10140020-01817-x

30. Rea G, Lassandro F, Lieto R, Bocchini G, Romano F, Sica G, Valente T, Muto E, Murino P, Pinto A, Montesarchio V, Muto M, Pacella D, Capitelli L, Bocchino M (2021) Lesson by SARS-CoV-2 disease (COVID-19): whole-body CT angiography detection of "relevant" and "other/incidental" systemic vascular findings. Eur Radiol 31(10):7363-7370. https://doi.org/10.1007/s0033 0-021-07904-y

31. Angeli E, Dalto S, Marchese S, Setti L, Bonacina M, Galli F, Rulli E, Torri V, Monti C, Meroni R, Beretta GD, Castoldi M, Bombardieri E (2021) Prognostic value of $C T$ integrated with clinical and laboratory data during the first peak of the COVID-19 pandemic in Northern Italy: A nomogram to predict unfavorable outcome. Eur J Radiol 137:109612. https://doi.org/10.1016/j.jra d.2021.109612

32. Persona P, Valeri I, Zarantonello F, Forin E, Sella N, Andreatta G, Correale C, Serra E, Boscolo A, Volpicelli G, Navalesi P (2021) Patients in intensive care unit for COVID-19 pneumonia: the lung ultrasound patterns at admission and discharge. An observational pilot study. Ultrasound J 13:10

33. Volpicelli G, Gargani L (2020) Sonographic signs and patterns of COVID-19 pneumonia. Ultrasound J 12(1):22. https://doi.org/10.1186/s13089-020-00171-w

34. Guarracino F, Vetrugno L, Forfori F, Corradi F, Orso D, Bertini P, Ortalda A, Federici N, Copetti R, Bove T (2021) Lung, Heart, Vascular, and Diaphragm Ultrasound Examination of COVID-19 Patients: A Comprehensive Approach. J Cardiothorac Vasc Anesth 35(6):1866-1874. https://doi.org/10.1053/j.jvca.2 020.06.013

35. Casella F, Barchiesi M, Leidi F, Russo G, Casazza G, Valerio G, Torzillo D, Ceriani E, Del Medico M, Brambilla AM, Mazziotti MA, Cogliati C (2021) Lung ultrasonography: A prognostic tool in non-ICU hospitalized patients with COVID-19 pneumonia. Eur J Intern Med 85:34-40. https://doi.org/10.1016/j. ejim.2020.12.012

36. Lazzeri C, Bonizzoli M, Batacchi S, Socci F, Matucci-Cerinic M, Peris A (2021) Combined lung and cardiac ultrasound in COVID-related acute respiratory distress syndrome. Intern Emerg Med (In press) 16(7):1779-1785. https://doi. org/10.1007/s11739-021-02646-7 
37. Gargani L, Soliman-Aboumarie H, Volpicelli G, Corradi F, Pastore MC, Cameli M (2020) Why, when, and how to use lung ultrasound during the COVID-19 pandemic: enthusiasm and caution. Eur Heart J Cardiovasc Imaging 21(9): 941-948. https://doi.org/10.1093/ehjci/jeaa163

38. Mongodi S, Orlando A, Arisi E, Tavazzi G, Santangelo E, Caneva L, Pozzi M, Pariani E, Bettini G, Maggio G, Perlini S, Preda L, lotti GA, Mojoli F (2020) Lung Ultrasound in Patients with Acute Respiratory Failure Reduces Conventional Imaging and Health Care Provider Exposure to COVID-19. Ultrasound Med Biol 46(8):2090-2093. https://doi.org/10.1016/j.ultra smedbio.2020.04.033

39. Campi I, Gennari L, Merlotti D, Mingiano C, Frosali A, Giovanelli L, Torlasco C, Pengo MF, Heilbron F, Soranna D, Zambon A, Di Stefano M, Aresta C, Bonomi M, Cangiano B, Favero V, Fatti L, Perego GB, Chiodini I, Parati G, Persani L (2021) Vitamin D and COVID-19 severity and related mortality: a prospective study in Italy. BMC Infect Dis 21(1):566. https://doi.org/10.1186/ s12879-021-06281-7

40. Figliozzi S, Masci PG, Ahmadi N, Tondi L, Koutli E, Aimo A, Stamatelopoulos K, Dimopoulos MA, Caforio ALP, Georgiopoulos G (2020) Predictors of adverse prognosis in COVID-19: A systematic review and meta-analysis. Eur J Clin Invest 50(10):e13362. https://doi.org/10.1111/eci.13362

41. Del Sole F, Farcomeni A, Loffredo L, Carnevale R, Menichelli D, Vicario T, Pignatelli P, Pastori D (2020) Features of severe COVID-19: A systematic review and meta-analysis. Eur J Clin Invest 50:e13378

42. Ruberto F, Chistolini A, Curreli M, Frati G, Marullo AGM, Biondi-Zoccai G, Mancone M, Sciarretta S, Miraldi F, Alessandri F, Ceccarelli G, Barone F, Santoro C, Alvaro D, Pugliese F, Pulcinelli FM (2021) Von Willebrand factor with increased binding capacity is associated with reduced platelet aggregation but enhanced agglutination in COVID-19 patients: another COVID-19 paradox? J Thromb Thrombolysis 52(1):105-110. https://doi.org/1 0.1007/s11239-020-02339-6

43. Vultaggio A, Vivarelli E, Virgili G, Lucenteforte E, Bartoloni A, Nozzoli C, Morettini A, Berni A, Malandrino D, Rossi O, Nencini F, Pieralli F, Peris A, Lagi F, Scocchera G, Spinicci M, Trotta M, Mazzetti M, Parronchi P, Cosmi L, Liotta F, Fontanari P, Mazzoni A, Salvati L, Maggi E, Annunziato F, Almerigogna F, Matucci A (2020) Prompt Predicting of Early Clinical Deterioration of Moderate-to-Severe COVID-19 Patients: Usefulness of a Combined Score Using IL-6 in a Preliminary Study. J Allergy Clin Immunol Pract 8(2575-2581): e2572

44. Mazzoni A, Salvati L, Maggi L, Capone M, Vanni A, Spinicci M, Mencarini J, Caporale R, Peruzzi B, Antonelli A, Trotta M, Zammarchi L, Ciani L, Gori L, Lazzeri C, Matucci A, Vultaggio A, Rossi O, Almerigogna F, Parronchi P, Fontanari P, Lavorini F, Peris A, Rossolini GM, Bartoloni A, Romagnani S, Liotta F, Annunziato F, Cosmi L (2020) Impaired immune cell cytotoxicity in severe COVID-19 is IL-6 dependent. J Clin Invest 130(9):4694-4703. https:// doi.org/10.1172/JCl138554

45. Toniati P, Piva S, Cattalini M, Garrafa E, Regola F, Castelli F, Franceschini F, Airo P, Bazzani C, Beindorf EA, Berlendis M, Bezzi M, Bossini N, Castellano M, Cattaneo S, Cavazzana I, Contessi GB, Crippa M, Delbarba A, De Peri E, Faletti A, Filippini M, Frassi M, Gaggiotti M, Gorla R, Lanspa M, Lorenzotti S, Marino R, Maroldi R, Metra M, Matteelli A, Modina D, Moioli G, Montani G, Muiesan ML, Odolini S, Peli E, Pesenti S, Pezzoli MC, Pirola I, Pozzi A, Proto A, Rasulo FA, Renisi G, Ricci C, Rizzoni D, Romanelli G, Rossi M, Salvetti M, Scolari F, Signorini L, Taglietti M, Tomasoni G, Tomasoni LR, Turla F, Valsecchi A, Zani D, Zuccala F, Zunica F, Foca E, Andreoli L, Latronico N (2020) Tocilizumab for the treatment of severe COVID-19 pneumonia with hyperinflammatory syndrome and acute respiratory failure: a single center study of 100 patients in Brescia, Italy. Autoimmun Rev 19(7):102568. https:// doi.org/10.1016/j.autrev.2020.102568

46. Castelnovo L, Tamburello A, Lurati A, Zaccara E, Marrazza MG, Olivetti M, Mumoli N, Mastroiacovo D, Colombo D, Ricchiuti E, Vigano P, Paola F, Mazzone A (2021) Anti-IL6 treatment of serious COVID-19 disease: a monocentric retrospective experience. Medicine (Baltimore) 100(1):e23582. https://doi.org/10.1097/MD.0000000000023582

47. Buonamico E, Quaranta VN, Boniello E, Dimitri M, Di Lecce V, Labate L, Pierucci P, Capozza E, Carpagnano GE, Resta O (2021) Risk factors for transfer from Respiratory Intermediate Care Unit to Intensive Care Unit in COVID-19. Respir Investig 59(5):602-607. https://doi.org/10.1016/j.resinv.2021. 05.002

48. Cattelan AM, Di Meco E, Trevenzoli M, Frater A, Ferrari A, Villano M, Gomiero F, Carretta G, Sasset L (2020) Clinical characteristics and laboratory biomarkers changes in COVID-19 patients requiring or not intensive or sub- intensive care: a comparative study. BMC Infect Dis 20(1):934. https://doi. org/10.1186/s12879-020-05647-7

49. Carlino MV, Valenti N, Cesaro F, Costanzo A, Cristiano G, Guarino M, Sforza A (2020) Predictors of Intensive Care Unit admission in patients with coronavirus disease 2019 (COVID-19). Monaldi Arch Chest Dis 90(3). https:// doi.org/10.4081/monaldi.2020.1410

50. Briguglio M, Crespi T, Pino F, Mazzocchi M, Porta M, De Vecchi E, Banfi G, Perazzo P (2021) Clinical Characteristics of Severe COVID-19 Patients Admitted to an Intensive Care Unit in Lombardy During the Italian Pandemic. Front Med (Lausanne) 8:582896. https://doi.org/10.3389/fmed.2 021.582896

51. Solimando AG, Susca N, Borrelli P, Prete M, Lauletta G, Pappagallo F, Buono R, Inglese G, Forina BM, Bochicchio D, Capobianco M, Carrieri V, Cicco S, Leone P, Silvestris N, Saracino A, Ria R, Procacci V, Migliore G, Vacca A, Racanelli V (2020) Short-Term Variations in Neutrophil-to-Lymphocyte and Urea-to-Creatinine Ratios Anticipate Intensive Care Unit Admission of COVID-19 Patients in the Emergency Department. Front Med (Lausanne) 7: 625176. https://doi.org/10.3389/fmed.2020.625176

52. Taramasso L, Vena A, Bovis F, Portunato F, Mora S, Dentone C, Delfino E, Mikulska M, Giacobbe DR, De Maria A, Magnasco L, Giacomini M, Di Biagio A, Bassetti M (2020) Higher Mortality and Intensive Care Unit Admissions in COVID-19 Patients with Liver Enzyme Elevations. Microorganisms 8(12). https://doi.org/10.3390/microorganisms8122010

53. Stefanini GG, Chiarito M, Ferrante G, Cannata F, Azzolini E, Viggiani G, De Marco A, Briani M, Bocciolone M, Bragato R, Corrada E, Gasparini GL, Marconi M, Monti L, Pagnotta PA, Panico C, Pini D, Regazzoli D, My I, Kallikourdis M, Ciccarelli M, Badalamenti S, Aghemo A, Reimers B, Condorelli G (2020) Early detection of elevated cardiac biomarkers to optimise risk stratification in patients with COVID-19. Heart 106(19):1512-1518. https://doi org/10.1136/heartjnl-2020-317322

54. Lodigiani C, lapichino G, Carenzo L, Cecconi M, Ferrazzi P, Sebastian T, Kucher N, Studt JD, Sacco C, Bertuzzi A, Sandri MT, Barco S (2020) Venous and arterial thromboembolic complications in COVID-19 patients admitted to an academic hospital in Milan, Italy. Thromb Res 191:9-14. https://doi. org/10.1016/j.thromres.2020.04.024

55. Grandone E, Tiscia G, Pesavento R, De Laurenzo A, Ceccato D, Sartori MT, Mirabella L, Cinnella G, Mastroianno M, Dalfino L, Colaizzo D, Vettor R, Intrieri M, Ostuni A, Margaglione M (2020) Use of low-molecular weight heparin, transfusion and mortality in COVID-19 patients not requiring ventilation. J Thromb Thrombolysis. (In press), DOI: https://doi.org/10.1007/ s11239-021-02460-0

56. Martinelli I, Ciavarella A, Abbattista M, Aliberti S, De Zan V, Folli C, Panigada M, Gori A, Artoni A, lerardi AM, Carrafiello G, Monzani V, Grasselli G, Blasi F, Peyvandi $F$ (2021) Increasing dosages of low-molecular-weight heparin in hospitalized patients with Covid-19. Intern Emerg Med 16(5):1223-1229. https://doi.org/10.1007/s11739-020-02585-9

57. Novelli C, Borotto E, Beverina I, Punzi V, Radrizzani D, Brando B (2021) Heparin dosage, level, and resistance in SARS-CoV2 infected patients in intensive care unit. Int J Lab Hematol (In press). https://doi.org/10.1111/ ijlh.13543

58. Fusina F, Albani F, Granato E, Meloni A, Rozzini R, Sabatini T, Stellini R, Terragnoli P, Rosano A, Abu Hilal M, Natalini G (2021) Effect of Corticosteroids on Mortality in Hospitalized COVID-19 Patients Not Receiving Invasive Mechanical Ventilation. Clin Pharmacol Ther 109(6):16601667. https://doi.org/10.1002/cpt.2245

59. Albani F, Fusina F, Granato E, Capotosto C, Ceracchi C, Gargaruti R, Santangelo G, Schiavone L, Taranto MS, Tosati C, Vavassori E, Natalini G (2021) Corticosteroid treatment has no effect on hospital mortality in COVID-19 patients. Sci Rep 11(1):1015. https://doi.org/10.1038/s41598-02080654-x

60. Salton F, Confalonieri P, Meduri GU, Santus P, Harari S, Scala R, Lanini S, Vertui V, Oggionni T, Caminati A, Patruno V, Tamburrini M, Scartabellati A, Parati M, Villani M, Radovanovic D, Tomassetti S, Ravaglia C, Poletti V, Vianello A, Gaccione AT, Guidelli L, Raccanelli R, Lucernoni P, Lacedonia D, Foschino Barbaro MP, Centanni S, Mondoni M, Davi M, Fantin A, Cao X, Torelli L, Zucchetto A, Montico M, Casarin A, Romagnoli M, Gasparini S, Bonifazi M, D'Agaro P, Marcello A, Licastro D, Ruaro B, Volpe MC, Umberger R, Confalonieri M (2020) Prolonged Low-Dose Methylprednisolone in Patients With Severe COVID-19 Pneumonia. Open Forum Infect Dis 7:ofaa421

61. Pasin L, Navalesi P, Zangrillo A, Kuzovlev A, Likhvantsev V, Hajjar LA, Fresilli S, Lacerda MVG, Landoni G (2021) Corticosteroids for patients with 
coronavirus disease 2019 (COVID-19) with different disease severity: a metaanalysis of randomized clinical trials. J Cardiothorac Vasc Anesth 35(2):578584. https://doi.org/10.1053/j.jvca.2020.11.057

62. Campochiaro C, Della-Torre E, Cavalli G, De Luca G, Ripa M, Boffini N, Tomelleri A, Baldissera E, Rovere-Querini P, Ruggeri A, Monti G, De Cobelli F, Zangrillo A, Tresoldi M, Castagna A, Dagna L (2020) Efficacy and safety of tocilizumab in severe COVID-19 patients: a single-centre retrospective cohort study. Eur J Intern Med 76:43-49. https://doi.org/10.1016/j.ejim.2020. 05.021

63. Salvati L, Occhipinti M, Gori L, Ciani L, Mazzoni A, Maggi L, Capone M, Parronchi P, Liotta F, Miele V, Annunziato F, Lavorini F, Cosmi L (2020) Pulmonary vascular improvement in severe COVID-19 patients treated with tocilizumab. Immunol Lett 228:122-128. https://doi.org/10.1016/j.imlet.202 0.10 .009

64. Coloretti I, Busani S, Biagioni E, Venturelli S, Munari E, Sita M, DallAra L, Tosi M, Clini E, Tonelli R, Fantini R, Mussini C, Meschiari M, Guaraldi G, Cossarizza A, Alfano G, Girardis M (2021) Effects of cytokine blocking agents on hospital mortality in patients admitted to ICU with acute respiratory distress syndrome by SARS-CoV-2 infection: retrospective cohort study. Multidiscip Respir Med 16:737. https://doi.org/10.4081/mrm.2021.737

65. Antinori S, Cossu MV, Ridolfo AL, Rech R, Bonazzetti C, Pagani G, Gubertini G, Coen M, Magni C, Castelli A, Borghi B, Colombo R, Giorgi R, Angeli E, Mileto D, Milazzo L, Vimercati S, Pellicciotta M, Corbellino M, Torre A, Rusconi S, Oreni L, Gismondo MR, Giacomelli A, Meroni L, Rizzardini G, Galli M (2020) Compassionate remdesivir treatment of severe COVID-19 pneumonia in intensive care unit (ICU) and non-ICU patients: clinical outcome and differences in post-treatment hospitalisation status. Pharmacol Res 158:104899. https://doi.org/10.1016/j.phrs.2020.104899

66. Lapadula G, Bernasconi DP, Bellani G, Soria A, Rona R, Bombino M, Avalli L, Rondelli E, Cortinovis B, Colombo E, Valsecchi MG, Migliorino GM, Bonfanti P, Foti G (2020) Remdesivir use in patients requiring mechanical ventilation due to COVID-19. Open Forum Infect Dis 7:ofaa481

67. Pasquini Z, Montalti R, Temperoni C, Canovari B, Mancini M, Tempesta M, Pimpini D, Zallocco N, Barchiesi F (2020) Effectiveness of remdesivir in patients with COVID-19 under mechanical ventilation in an Italian ICU. J Antimicrob Chemother 75(11):3359-3365. https://doi.org/10.1093/jac/ dkaa321

68. Langford BJ, So M, Raybardhan S, Leung V, Westwood D, MacFadden DR, Soucy JR, Daneman N (2020) Bacterial co-infection and secondary infection in patients with COVID-19: a living rapid review and meta-analysis. Clin Microbiol Infect 26(12):1622-1629. https://doi.org/10.1016/j.cmi.2020.07.016

69. De Santis V, Corona A, Vitale D, Nencini C, Potalivo A, Prete A, Zani G, Malfatto A, Tritapepe L, Taddei S, Locatelli A, Sambri V, Fusari M, Singer M (2021) Bacterial infections in critically ill patients with SARS-2-COVID-19 infection: results of a prospective observational multicenter study. Infection. (In press), DOl: https://doi.org/10.1007/s15010-021-01661-2

70. Fattorini L, Creti R, Palma C, Pantosti A (2020) Bacterial coinfections in COVID-19: an underestimated adversary. Ann Ist Super Sanita 56(3):359-364. https://doi.org/10.4415/ANN_20_03_14

71. Pascale R, Bussini L, Gaibani P, Bovo F, Fornaro G, Lombardo D, Ambretti S, Pensalfine G, Appolloni L, Bartoletti M, Tedeschi S, Tumietto F, Lewis R, Viale P, Giannella M (2021) Carbapenem-resistant bacteria in an intensive care unit during the coronavirus disease 2019 (COVID-19) pandemic: a multicenter before-and-after cross-sectional study. Infect Control Hosp Epidemiol:1-6. https://doi.org/10.1017/ice.2021.144

72. Pasero D, Cossu AP, Terragni P (2021) Multi-drug resistance bacterial infections in Critically III Patients Admitted with COVID-19. Microorganisms 9:1773

73. Foschi C, Zignoli A, Gaibani P, Vocale C, Rossini G, Lafratta S, Liberatore A, Turello G, Lazzarotto T, Ambretti S (2021) Respiratory bacterial co-infections in intensive care unit-hospitalized COVID-19 patients: conventional culture vs BioFire FilmArray pneumonia Plus panel. J Microbiol Methods 2021: 106259. https://doi.org/10.1016/j.mimet.2021.106259

74. Moretti M, Van Laethem J, Minini A, Pierard D, Malbrain M (2021) Ventilatorassociated bacterial pneumonia in coronavirus 2019 disease, a retrospective monocentric cohort study. J Infect Chemother 27(6):826-833. https://doi. org/10.1016/j.jiac.2021.01.011

75. Cataldo MA, Tetaj N, Selleri M, Marchioni L, Capone A, Caraffa E, Caro AD, Petrosillo N (2020) Incidence of bacterial and fungal bloodstream infections in COVID-19 patients in intensive care: an alarming "collateral effect". J Glob Antimicrob Resist 23:290-291. https://doi.org/10.1016/j.jgar.2020.10.004
76. Antinori S, Galimberti L, Milazzo L, Ridolfo AL (2020) Bacterial and fungal infections among patients with SARS-CoV-2 pneumonia. Infez Med 28(suppl 1):29-36

77. Maddaloni E, D'Onofrio L, Alessandri F, Mignogna C, Leto G, Pascarella G, Mezzaroma I, Lichtner M, Pozzilli P, Agro FE, Rocco M, Pugliese F, Lenzi A, Holman RR, Mastroianni CM, Buzzetti R (2020) Cardiometabolic multimorbidity is associated with a worse Covid-19 prognosis than individual cardiometabolic risk factors: a multicentre retrospective study (CoViDiab II). Cardiovasc Diabetol 19(1):164. https://doi.org/10.1186/s12933020-01140-2

78. Zangrillo A, Beretta L, Scandroglio AM, Monti G, Fominskiy E, Colombo S, Morselli F, Belletti A, Silvani P, Crivellari M, Monaco F, Azzolini ML, Reineke R, Nardelli P, Sartorelli M, Votta CD, Ruggeri A, Ciceri F, De Cobelli F, Tresoldi M, Dagna L, Rovere-Querini P, Serpa Neto A, Bellomo R, Landoni G (2020) Characteristics, treatment, outcomes and cause of death of invasively ventilated patients with COVID-19 ARDS in Milan, Italy. Crit Care Resusc 22(3):200-211

79. Fadini GP, Morieri ML, Boscari F, Fioretto P, Maran A, Busetto L, Bonora BM, Selmin E, Arcidiacono G, Pinelli S, Farnia F, Falaguasta D, Russo L, Voltan G, Mazzocut S, Costantini G, Ghirardini F, Tresso S, Cattelan AM, Vianello A, Avogaro A, Vettor R (2020) Newly-diagnosed diabetes and admission hyperglycemia predict COVID-19 severity by aggravating respiratory deterioration. Diabetes Res Clin Pract 168:108374. https://doi.org/10.1016/j. diabres.2020.108374

80. Lazzeri C, Bonizzoli M, Batacchi S, Cianchi G, Franci A, Fulceri GE, Peris A (2020) Cardiac involvment in COVID-19-related acute respiratory distress syndrome. Am J Cardiol 132:147-149. https://doi.org/10.1016/j.amjcard.2020. 07.010

81. Biscarini S, Colaneri M, Ludovisi S, Seminari E, Pieri TC, Valsecchi P, Gallazzi I, Giusti E, Camma C, Zuccaro V, Mondelli MU (2020) The obesity paradox: analysis from the SMAtteo COvid-19 REgistry (SMACORE) cohort. Nutr Metab Cardiovasc Dis 30:1920-1925

82. Rottoli M, Bernante P, Belvedere A, Balsamo F, Garelli S, Giannella M, Cascavilla A, Tedeschi S, lanniruberto S, Rosselli Del Turco E, Tonetti T, Ranieri VM, Poggioli G, Manzoli L, Pagotto U, Viale P, Bartoletti M (2020) How important is obesity as a risk factor for respiratory failure, intensive care admission and death in hospitalised COVID-19 patients? Results from a single Italian centre. Eur J Endocrinol 183(4):389-397. https://doi.org/10.153 0/EJE-20-0541

83. Watanabe M, Caruso D, Tuccinardi D, Risi R, Zerunian M, Polici M, Pucciarelli F, Tarallo M, Strigari L, Manfrini S, Mariani S, Basciani S, Lubrano C, Laghi A, Gnessi L (2020) Visceral fat shows the strongest association with the need of intensive care in patients with COVID-19. Metabolism 111:154319. https:// doi.org/10.1016/j.metabol.2020.154319

84. Rossi AP, Gottin L, Donadello K, Schweiger V, Brandimarte P, Zamboni GA, Florio A, Boetti R, Pavan G, Zamboni M, Polati E (2021) Intermuscular adipose tissue as a risk factor for mortality and muscle injury in critically ill patients affected by COVID-19. Front Physiol 12:651167. https://doi.org/10.33 89/fphys.2021.651167

85. Masetti C, Generali E, Colapietro F, Voza A, Cecconi M, Messina A, Omodei P, Angelini C, Ciccarelli M, Badalamenti S, Canonica GW, Lleo A, Aghemo A (2020) High mortality in COVID-19 patients with mild respiratory disease. Eur J Clin Invest 50(9):e13314. https://doi.org/10.1111/eci.13314

86. Venturini S, Orso D, Cugini F, Crapis M, Fossati S, Callegari A, Pellis T, Tonizzo M, Grembiale A, Rosso A, Tamburrini M, D'Andrea N, Vetrugno L, Bove T (2021) Classification and analysis of outcome predictors in non-critically ill COVID-19 patients. Intern Med J 51(4):506-514. https://doi.org/10.1111/imj.15140

87. Zinellu A, Mangoni AA (2021) Serum prealbumin concentrations, COVID-19 severity, and mortality: a systematic review and meta-analysis. Front Med (Lausanne) 8:638529. https://doi.org/10.3389/fmed.2021.638529

88. Berni A, Malandrino D, Corona G, Maggi M, Parenti G, Fibbi B, Poggesi L, Bartoloni A, Lavorini F, Fanelli A, Scocchera G, Nozzoli C, Peris A, Pieralli F, Pini R, Ungar A, Peri A (2021) Serum sodium alterations in SARS CoV-2 (COVID-19) infection: impact on patient outcome. Eur J Endocrinol 185(1): 137-144. https://doi.org/10.1530/EJE-20-1447

89. Tramontana F, Napoli N, El-Hajj Fuleihan G, Strollo R (2020) The D-side of COVID-19: musculoskeletal benefits of vitamin $D$ and beyond. Endocrine 69(2):237-240. https://doi.org/10.1007/s12020-020-02407-0

90. Montrucchio G, Sales G, Rumbolo F, Palmesino F, Fanelli V, Urbino R, Filippini C, Mengozzi G, Brazzi L (2021) Effectiveness of mid-regional proadrenomedullin (MR-proADM) as prognostic marker in COVID-19 critically ill 
patients: an observational prospective study. PLoS One 16(2):e246771. https://doi.org/10.1371/journal.pone.0246771

91. Fumagalli C, Rozzini R, Vannini M, Coccia F, Cesaroni G, Mazzeo F, Cola M, Bartoloni A, Fontanari P, Lavorini F, Marcucci R, Morettini A, Nozzoli C, Peris A, Pieralli F, Pini R, Poggesi L, Ungar A, Fumagalli S, Marchionni N (2020) Clinical risk score to predict in-hospital mortality in COVID-19 patients: a retrospective cohort study. BMJ Open 10(9):e040729. https://doi.org/10.113 6/bmjopen-2020-040729

92. Biagioni E, Tosi M, Berlot G, Castiglione G, Corona A, De Cristofaro MG, Donati A, Feltracco P, Forfori F, Fragranza F, Murino P, Piazza O, Tullo L, Grasselli G, D'Amico R, Girardis M (2021) Adjunctive IgM-enriched immunoglobulin therapy with a personalised dose based on serum IgMtitres versus standard dose in the treatment of septic shock: a randomised controlled trial (lgM-fat trial). BMJ Open 11(2):e036616. https://doi.org/10.113 6/bmjopen-2019-036616

93. Lissoni B, Del Negro S, Brioschi P, Casella G, Fontana I, Bruni C, Lamiani G (2020) Promoting resilience in the acute phase of the COVID-19 pandemic psychological interventions for intensive care unit (ICU) clinicians and family members. Psychol Trauma 12(S1):S105-S107. https://doi.org/10.1037/tra 0000802

94. Mistraletti G, Gristina G, Mascarin S, lacobone E, Giubbilo I, Bonfanti S, Fiocca F, Fullin G, Fuselli E, Bocci MG, Mazzon D, Giusti GD, Galazzi A, Negro A, De laco F, Gandolfo E, Lamiani G, Del Negro S, Monti L, Salvago F, Di Leo S, Gribaudi MN, Piccinni M, Riccioni L, Giannini A, Livigni S, Maglione C, Vergano M, Marinangeli F, Lovato L, Mezzetti A, Drigo E, Vegni E, Calva S, Aprile A, Losi G, Fontanella L, Calegari G, Ansaloni C, Pugliese FR, Manca S, Orsi L, Moggia F, Scelsi S, Corcione A, Petrini F (2020) How to communicate with families living in complete isolation. BMJ Support Palliat Care. (In press)

95. Benatti SV (2020) Love in the Time of Corona. Ann Intern Med 172(9):628. https://doi.org/10.7326/M20-1137

96. Carlucci M, Carpagnano LF, Dalfino L, Grasso S, Migliore G (2020) Stand by me 2.0. Visits by family members at COVID-19 time. Acta Biomed 91(2):7174. https://doi.org/10.23750/abm.v91i2.9569

97. Franchini S, Spessot M, Landoni G, Piani C, Cappelletti C, Mariani F, Mauri S, Taglietti MV, Fortunato M, Furlan F, Guglielmi B, Setti E, Di Napoli D, Borghi G, Pascucci F, Ujlaki-Formenti G, Sannicandro R, Moro M, Colombo S, Dagna L, Castagna A, Tresoldi M, Rovere-Querini P, Ambrosio A, Ciceri F, Zangrillo A, Carlucci M, Faccincani R (2020) Stranger months: how SARS-CoV-2, fear of contagion, and lockdown measures impacted attendance and clinical activity during February and March 2020 at an urban emergency department in Milan. Disaster Med Public Health Prep:1-10. https://doi.org/1 $0.1017 / \mathrm{dmp} .2020 .265$

98. Cammarota G, Ragazzoni L, Capuzzi F, Pulvirenti S, De Vita N, Santangelo E, Verdina F, Grossi F, Vaschetto R, Della Corte F (2020) Critical care surge capacity to respond to the COVID-19 pandemic in Italy: a rapid and affordable solution in the Novara Hospital. Prehosp Disaster Med 35(4):431433. https://doi.org/10.1017/S1049023X20000692

99. Carretta G, Contessa C, Boemo DG, Bordignon G, Bennici SE, Merigliano S, Boschetto M, Capizzi A, Cattelan A, Causin F, Cianci V, Flor L, Friziero A, Navalesi P, Nesoti MV, Saieva AM, Scapellato M, Tiberio I, Vettor R, Vianello A, Salvador R, Donato D (2020) COVID-19 challenge: proactive management of a tertiary university hospital in Veneto Region, Italy. Pathog Glob Health 114(6):309-317. https://doi.org/10.1080/20477724.2020.1806614

100. Comelli I, Scioscioli F, Cervellin G (2020) Impact of the COVID-19 epidemic on census, organization and activity of a large urban emergency department. Acta Biomed 91(2):45-49. https://doi.org/10.23750/abm.v91i2.9565

101. Berardi G, Colasanti M, Levi Sandri GB, Del Basso C, Ferretti S, Laurenzi A, Guglielmo N, Meniconi RL, Antonini M, D'Offizi G, Ettorre GM (2020) Continuing our work: transplant surgery and surgical oncology in a tertiary referral COVID-19 center. Updates Surg 72(2):281-289. https://doi.org/10.1 007/s13304-020-00825-3

102. Carenzo L, Costantini E, Greco M, Barra FL, Rendiniello V, Mainetti M, Bui R, Zanella A, Grasselli G, Lagioia M, Protti A, Cecconi M (2020) Hospital surge capacity in a tertiary emergency referral centre during the COVID-19 outbreak in Italy. Anaesthesia 75(7):928-934. https:/doi.org/10.1111/anae.15072

103. Agnoletti V, Russo E, Circelli A, Benni M, Bolondi G, Martino C, Santonastaso DP, Brogi E, Pratic OB, Coccolini F, Fugazzola P, Ansaloni L, Gamberini E (2021) From intensive care to step-down units: managing patients throughput in response to COVID-19. International J Qual Health Care 33(1). https://doi.org/10.1093/intghc/mzaa091
104. Grasselli G, Pesenti A, Cecconi M (2020) Critical care utilization for the COVID-19 outbreak in Lombardy, Italy: early experience and forecast during an emergency response. JAMA 323(16):1545-1546. https://doi.org/10.1001/ja ma.2020.4031

\section{Publisher's Note}

Springer Nature remains neutral with regard to jurisdictional claims in published maps and institutional affiliations.

\section{Ready to submit your research? Choose BMC and benefit from:}

- fast, convenient online submission

- thorough peer review by experienced researchers in your field

- rapid publication on acceptance

- support for research data, including large and complex data types

- gold Open Access which fosters wider collaboration and increased citations

- maximum visibility for your research: over $100 \mathrm{M}$ website views per year

At BMC, research is always in progress.

Learn more biomedcentral.com/submissions 